\title{
FROM HEALING TO HOPE: \\ The Continuing Influence of the Chilean Arpilleras
}

\author{
T. Randahl Morris, Ph.D., APR \\ University of West Georgia \\ trmorris@westga.edu
}

\begin{abstract}
Since the 1970s, instances of widespread societal terror and extermination have proliferated. The source of such conflicts may involve entities outside of a country but, often, the parties involved in the conflict are states and their citizens. These types of social injustices and human rights atrocities tear apart the very fabric of a society, often resulting from internal wars which pit people who previously lived side-by-side against one another.

A constant in these conflicts is the silencing of communication on many levels which creates an opening for multiple forms of art to function as communicative media, visual testimony, and human rights violations documentation.

This paper studies the processes though which oppressed people are able to create and export visual testimonial art and the conditions that may increase the likelihood of success.

The 40-year history of Chilean arpilleras, commonly referred to as political quilts, is used as a case study to identify five phases of the arpilleras which directly correlate to the creators' lived experience: trauma, survival, healing and recovering, and remembering. The role of oppressors (the Chilean military) and supporters (those who created protected spaces and facilitated movement of the arpilleras) is analyzed in two ways: through their familiar form, which gave the impression that the arpilleras were a safe women's craft; and through their distinctive features, which created openings for the arpilleras to communicate in an international court of public opinion what the oppressors sought to silence. The fifth phase of the arpilleras, continuing circulation, provides an opportunity to examine how the arpilleras are used as models for subversive communication and in healing and reconciliation efforts.

This close examination of the Chilean arpilleras as visual testimony and communicative art illustrates their contributions to social justice and peace.
\end{abstract}

\section{Keywords}

documentation, healing, narrative, peace, reconciliation, truth 


\section{About the Author}

T. Randahl Morris, PhD, APR, is an assistant professor at the University of West Georgia (US) in the Department of Mass Communications. Her research interests include communication processes related to human rights, social justice, testimony, public diplomacy, and public relations. Dr. Morris' publications, conferences, presentations, and research include the study of human rights issues in Chile, Syria, Iraq and South Africa. Her communications focus includes written, oral, and visual manifestations of testimony that are produced and reproduced in official and unofficial publications and venues as well as traditional and new media. Dr. Morris is past chair of the National Communication Association Visual Communication Division Board. 
The bright patchwork scenes made of cloth and fiber with elements such as tiny dolls and yarn-embroidered edges seem hauntingly familiar and exude an almost hypnotic aura. "Come closer, let us share our story with you," they seem to whisper. On closer inspection it becomes apparent that these are not ordinary scenes of domestic life. Rather, these are scenes of abduction and torture, death and conspiracy. And, like the mysterious and devious circumstances that led to the creation of these testimonial textiles, the patchwork stories-masquerading as common women's sewing work-subversively documented the darkest sides of the Augusto Pinochet military dictatorship in Chile for nearly 20 years.

The women who crafted the arpilleras-named after the hessian backing recycled from old produce sacks-worked secretly to tell their tales. And when they were done, they would cautiously deliver the textiles to the collection point where a carefully orchestrated volunteer network smuggled them out of Chile and delivered them to distribution points throughout the United States and Europe.

Although Pinochet is long-dead, the arpilleras live on. Serving as a model for documentation, healing, and remembrance, the arpilleras successfully documented testimony about social justice issues and became a distinctive art form. More than 40 years after the perpetrators of human rights abuses and systematic genocide first began attacking their own citizens, the arpilleras documenting the atrocities still continue to circulate around the world. Within the last 10 years, 30 workshops and arpillera exhibits have been curated in a dozen different countries. The question to be addressed is how have the arpilleras continued to circulate and have international influence for more than four decades after they were first created.

The women who crafted the arpilleras, and their family members, survived being detained, traumatized, and tortured, though some were exterminated by the dictatorship. After the 1973 military take-over of the Salvador Allende government, the women, whose partners and children disappeared without a trace through actions of the military and secret police, became primary targets of ongoing terror campaigns.

These women chose "la vida"-life-over hiding, desperation, and death. Central to their reclamation of life and agency was participation in arpillera workshops organized under the protection of the Pro Paz Committee and later the Vicaria of Solidarity and the Catholic Church. Because of these protected spaces, the women were able to begin healing physically and emotionally and to eventually transform themselves into peaceful protestors and social justice advocates. The legacy of their artistic endeavors has expanded past geographic and cultural boundaries due to mimesis of the form which has been used as a model for memorializing human rights violations throughout the world. The transcendence of the arpilleras to 
visual testimony of human rights atrocities and to a model art form attests to the relevance of the form to aid in healing, remembering, and documenting.

Sometimes referred to as textiles, ${ }^{1}$ protest quilts, women's work, or place mats, arpilleras represent a distinct genre of resistance communication that intersects with familiar art forms such as quilts, wall hangings, crocheting, and knitting. It is the familiarity of the form, not its distinction that enabled the arpilleras to initially circulate across borders. Yet it is the distinctions related to the embedded narratives and messages that have contributed to the ongoing communicative success of the arpilleras.

Reviewing the 40-year history of the Chilean arpilleras, the context in which they were conceived, created, and circulated, and the circumstances under which they still continue to circulate, illustrates the transformative power of testimonial art and how it impacts social justice.

\section{THE USE OF ART AS TESTIMONY AND PEACEFUL PROTEST DURING CHILE'S TIME OF STATE TERROR}

The military invasion of Chile on Sept. 11, 1973, the reported suicide of President Allende, and the immediate onset of disappearances and detentions signalling an onslaught of state terror against its own citizens surprised people at many different levels. Mark Ensalaco reports that many people went willingly to be questioned by police after hearing their name on the radio, many of whom were never seen again (28). Many people simply could not fathom that the Chile they knew no longer existed; a new regime was in control and the rules diverged drastically from those of the previous civil society.

While many people were desperate to communicate the atrocities overtaking their country, Chile's isolated political status all but assured that getting information across the border would be no easy feat. Access to communicative technology and the traditional forms of the press was extremely low and the harsh military rule made communicating a high risk. A virtual shutdown of the press and citizens' ability to speak freely indicate that Chile was a closed system, one which neither allowed communication out of or into the country. Despite the efforts of human rights groups and influential religious organizations, the magnitude and swiftness

of the military control could not be adequately communicated or understood (Ensalaco 2000; Cooper 2001).

Ironically, the only people who had any chance of trying to communicate were those with the least power: the wives and mothers left behind once the military 
exterminated the men. ${ }^{2}$ Pushed aside by society and considered inconsequential by Pinochet's command, initially the women were able to fly under the radar in their efforts to communicate the human rights violations. Their medium-scraps of cloth in a loose patchwork design-expressed the plight of the people in human terms easily understood and felt through scenes portrayed with fabric, sometimes from the clothing of the dead, in organically quilted scenes that depicted specific examples of abduction, torture, and death. The resulting testimony, in the form of arpilleras, ${ }^{3}$ was then smuggled out of the country. Throughout the world people bought the arpilleras in solidarity for the plight of the Chilean people and as a way to help the women earn money to feed their families. Peter Kornbluh notes that these efforts also resulted in conversations about what was happening in Chile with the women creators becoming "artistic ambassadors" in the international push to improve human rights (9). ${ }^{4}$

During the occupation, international media and human rights organizations attempted to chronicle the events occurring within the country. As Chileans fled the country, autobiographical and biographical accounts began to appear in various media and books. Official testimony appears in the body of two truth commission reports. However, despite the enormous amount of evidence and increasing determination of the Chilean people, it would be nearly 18 years before Chile would have its first democratically elected president.

In 1989, Chilean President Patricio Aylwin entered into one of the most critical periods in more than 150 years of independence, what Ensalaco calls a time in which the virtue of truth was mixed with the virtue of prudence (236). Aylwin was attempting to persuade all stakeholders to make the transition from a militaristic dictatorship to a democratic state and, along with it, to return of freedoms that vanished with the overthrow of President Allende in 1973. Within the first three months of the Pinochet dictatorship, nearly 18,00o Chileans were detained, questioned, and tortured by their own countrymen (Bacic and Stanley 2). Aylwin, as the new president nearly 20 years later, was faced with the dubious task of trying to move a country forward while the military still held considerable power and the courts had proven to be ineffective. Aylwin's first step was to establish a presidential ${ }^{6}$ commission with the task of discovering the "whole" truth about the missing and detained people-which now numbered in the tens of thousandsand to determine the scope of the atrocities.

The National Commission for Truth and Reconciliation ultimately was presented with 3,400 death cases and concluded that 94 percent were caused by government agents. A 1,200-page report covered logistics (commission objectives, truth indicators, court evidence, as well as reparation and prevention proposals), the context within which the human rights violations occurred (political, legal and 
institutional frameworks), war tribunals, court behavior during the military junta, the impact of the violations, and recommendations. Nearly 1,00o pages of the document were dedicated to testimony, analysis, and societal reactions (Chilean National Commission 2002).

Although President Aylwin announced in a 1991 televised broadcast that he was satisfied that the truth of the occurrence of the human rights violations had been established and could not be denied, the process and results were fraught with controversy. The policy of "no naming" those involved in the crimes was highly criticized but managed to placate the still strong and volatile military establishment which refused to come forth with information about the missing people (Aguilar 50). ${ }^{7}$ With the establishment of a Corporation for Reparations and Reconciliation, the process continued and the number of cases nearly doubled as more people came forward. Efforts continued to be hindered by a strong military presence, the transitional nature of the country, deliberate perpetrator interference, and stonewalling (Ensalaco 200o).

More than 10 years later, a second truth and reconciliation process would commence to attempt to do what the first commission was unable to complete. ${ }^{8}$ What, however, was left behind were the official testimonies that family members, friends, witnesses, testimony takers, human rights attorneys, support staff and commission members had labored over in an attempt to put together a comprehensive and accurate picture of those military years. These testimonies often were incomplete and consistently overly simplistic, many times with a life story reduced to a sentence. The lack of information from perpetrators due to either arrogance or fear of incrimination has been well documented. A Chilean human rights worker sums up the issues of the time: "You must realize that at the time that testimony was taken, the military still had full power. The minimum would be in the report. The name, profession. The military didn't want to be named. It was an abstract."

\section{FIVE PHASES OF THE ARPILLERAS}

In contrast to the official testimony, unofficial testimony by survivors lives on in spaces such as museums, memorial sites, and publications. The arpilleras, functioning as cloth archives that depict specific instances of abductions and disappearances, communicate without the burden of politically correct language often expressed in official proceedings and written truth commission reports. The arpilleras document atrocities in a way that cannot be contested when the words become compromised due to conflicting objectives for reconciliation. Erik Doxtader indicates that the process of reconciliation creates a time of diminished 
or transitional truth, a turn from the law to create a space for coming together (19). This "middle voice" cannot emerge until a time of kairos, when the two opposing sides are finally willing to come together to share opposition in an effort to find common ground for moving toward working together (20). Ironically, this middle voice creates a shared narrative that may help to move a fractured society forward but is too concise to be consistent with the needs of indivduals and families to recognize and memorialize victims of human rights abuses.

In contrast to the rhetoric of transitional justice, testimonial arts created during a time of oppression are unique because they communicate truth in a nonthreatening form that often facilitates a safe environment for disclosure by both the creator and the audience; yet, the distinct aspect of the truth of testimonial art is that it is never diminished because the images remain as concrete representations of what has happened.

The continuum of the arpilleras is characterized by five stages that roughly correlate to the historical events of the Chilean military terror campaign against the populace and the changing emotional state and subjectivity of the women who created the arpilleras (see Fig. 1. Life Cycle of the Arpilleras). The subjects or groups associated with the arpilleras consist of the arpilleristas as creators, the military junta as oppressors, and the supporters. Of the three groups, the supporters-which include church officials, human rights workers, individuals, and other helping groups-have been primarily responsible for the international prominence of the arpilleras and their continuing circulation.

The first phase of the arpilleras - trauma-began with the government seizure, led by Augusto Pinochet and the four branches of the military in September of 1973. Detentions and disappearances began immediately and the women left behind were thrown into a life that required them to be breadwinners, heads of household, and investigators - all without prior experience or training. The terror of the time was so acute that their physical bodies were frozen with fear. The arpilleras during this time were experimental, a form of therapy for the women who gathered in church-sponsored groups to share experiences and ideas about how to find their missing relatives. The contributions to social justice were to give the women a safe, communal space where they could express themselves and to stitch stories that could not yet be spoken due to their traumatized states and for of retribution by the military. As creators, the women did not initially attach a great deal of importance to the small crafts. The oppressors ignored the sewing projects, seeing them as harmless women's work. The primary supporters were the church organizations, first the Pro Paz then the Vicaria of Solidarity, and the workshop organizers who saw the small crafts as a way for the women to deal with their emotions. For many 
it was a way to communicate about what happened without talking about it (see Fig. 2).

In the second phase of the arpilleras-survival-the supporters began to set up sales through local craft fairs to provide a small stipend for the women. Supporters began to take arpilleras out of the country, selling them in their own locales, and sending the money back to the workshops in Chile. The creators began to organize their thoughts and techniques about how to make the arpilleras. The scenes reflected their daily living including specific instances of oppression, torture, and disappearance. These forms of visual testimony made the arpilleras distinct from other types of textiles people were accustomed to seeing. The form of the arpilleras-stories told in old, worn cloth, sometimes from the clothing of the disappeared-made the arpilleras seem familiar yet distinctive because they were so poignant and compelling. The contributions to social justice included giving the women a way to regain their voices, to earn money to support their families, and to begin to gain recognition outside Chile that human rights violations were occurring. The oppressors continued to relegate the small quilts to the realm of harmless crafts (See Fig. 3).

In the third phase of healing and recovery, the use of the arpilleras began to shift and gain momentum. As the years passed, the arpilleristas began to regain their confidence and ability to speak out against the continuing military oppression. The women realized that their arpilleras were distinct and an important vehicle for communicating the details of disappearances to a global audience. Their increasing confidence was evidenced in public group protests within Chile. Messages substantiating human rights violations were embedded within the arpilleras either as part of the visual story or on small scraps of paper tucked into hidden pockets on the arpilleras. In 1980, nearly seven years after the first arpilleras were made, the Pinochet government renounced the arpilleras as subversive in a series of articles in government-controlled newspapers, and the arpilleras were banned..$^{10}$ Recorded testimony of the women tells of them working on the arpilleras at night, while hiding under blankets with candles. Getting the arpilleras to the workshops was a trip fraught with the fear that they would be caught and tortured.

During this period, the increased credibility of the arpilleras served to further the Chilean people's claims of oppression and human rights violations, but it would be another nine years before a democratic election would take place. While some scholars contend that the women worked within their traditional roles, Jean Franco argues that the women "substantially altered tradition by casting themselves a new kind of citizen and appealing beyond the state to international organizations" (50). (See Fig. 4.) 
Remembering, as the fourth phase of the arpilleras, also encompasses the commitment of the women to continue seeking the truth. Franco notes that not only did family members die, the public sphere died as well (52). The memorializing evident in the arpilleras was for missing bodies as well as missing cultural and social traditions. The arpilleras functioned as circulating memorials of the disappeared, symbolically reinforced beliefs such as faith in the church and the strength of community, and also identified social issues that needed to be addressed and corrected. The women used the familiarity of private life as the backdrop for their woven scenes and made it distinctive by contrasting it with visuals of the military in direct opposition to their rhetoric of the state acting as protectors of the people (see Fig. 5).

The women took pride in the realization that their arpilleras were in other countries and were encouraged that others found them of value. The distinction of the arpilleras increased among oppressors as they realized that merely banning the arpilleras was not going to eliminate the threat. The form of the arpilleras was appropriated by the regime to visually express pro-government messages and these forgeries were passed as legitimate arpilleras. Government-run arpillera workshops featured arpilleras with themes of happiness and prosperity which were sold to tourists. Supporters continued to smuggle the subversive textiles out of the country and the arpillera continued to gain value as archives of a time when basic freedoms were denied and the written and spoken word was suppressed.

The continuing circulation of the arpilleras is the fifth phase of the arpilleras and continues today, nearly 40 years since they were first fashioned of scraps and attached to recycled hessian bean and flour sacks. The arpilleristas' legacy lives on in what is now a distinctive art form that is used as a model for subversive communication and healing in other countries such as Peru, Zimbabwe, and Northern Ireland ${ }^{11}$ (see Fig. 6-8).

The interplay of these three spheres of creator, oppressor, and supporter creates an environment in which social justice can begin, exist, and potentially grow outside the boundaries of an oppressed society. Arjun Appadurai's writings on the production of locality is relevant to such an environment because the ongoing recreation of the arpillera can be seen as a ritualistic manifestation of the missing bodies and as an effort to visually and symbolically keep their communities alive despite the military efforts to control and suppress access to even the most basic needs such as water and electricity. The resulting ethnoscape is important, says Appadurai, because it informs us on the "relationship between local and global realities" and leads to discourse within a spatiotemporal neighborhood (185). The international circulation of the arpilleras creates local and global neighborhoods which facilitate their continuing circulation and appropriation. 
Importantly, the arpilleras have inspired other subversive efforts and communicative art projects throughout the world. Among the best known arpillerainspired projects are those made by the Kuyanaky, a collective of displaced Andean women in Peru. The women lost their homes and community during the civil war of 1980 to 2000 , but by working together, they were able to make individual and collective arpilleras that showed the devastation of the war and contrasted the past with the present. The largest of these Peruvian arpilleras was presented to the Truth and Reconciliation Commission in Peru in 2002, was publicly displayed at court proceedings, and featured during in 2008 at the Art of Survival exhibit at the International Quilt show, in Derry, Northern Ireland (see Fig. 6).

During this same period, the community of Derry was commemorating the $10^{\text {th }}$ anniversary of the Good Friday agreement that brought about peace after the many years of the "troubles." The Irish women produced arpilleras in remembrance of the more than 3,00o people who were killed during those times. The Irish quilts, like the Chilean ones before them, facilitated group conversation, healing, and remembrance (See Fig. 8).

Human rights workers have hosted numerous arpilleras exhibits and talks within the last few years in places as far-flung as Russia, England, the United States, Spain, and the Chilean government embraced arpilleras as "ambassadors" for their 2010 biennial celebrations worldwide. ${ }^{12}$

Although the original oppressors are no longer in official positions of power, the oppression lives on for many people because of the lack of justice in prosecuting those responsible for the deaths and torture. However, in the new memorial museum, opened in Santiago in January 2010, arpilleras are featured as a key example of citizen efforts to communicate with the world outside Chile.

The arpilleras have also been embraced on a micro scale. Among teachers internationally, arpilleras are used as tools for learning about human rights atrocities. Facing History, an international pedagogical effort with more than 126,00o members, has a multi-part curriculum on their website titled: Stitching Truth. In the US, arpilleras are used by educators for class activities covering disparate subjects. In 2009, a teacher from Decatur, Georgia, for example, received a mini-grant for an elementary school arpillera project that featured the solar system. The arpilleras, as when they were first created, continue to speak to many people on many levels. 


\section{APPLICATION OF DISTINCTION AND MORAL SCALE TO THE ARPILLERA LIFE CYCLE}

Throughout their long history, the arpilleras have evolved through time, circumstance, and usage. The original arpilleras and the arpilleras, as a testimonial art form, have been used, copied, appropriated, and adapted by various groups for diverse purposes.

Henry Jenkins notes that Michel de Certeau's theory of appropriation allows for "competing and contradictory interpretations" of text based on divergent needs and perspectives resulting in multiple, changing meanings that are affected by numerous factors $(32-34)$. These differences result in fluid meanings that change and shift with time and circumstance. In the case of the arpilleras, it is possible to look at the development of the arpilleras as a continuum and to triangulate this timeline of development with the primary actors (creators, oppressors, supporters) and the concept of familiar yet distinct to begin to uncover a rich picture of the relationship between the arpilleras as object and the arpilleras as a catalyst for social justice.

Additionally, Igor Kopytoff's discussion of the multi-centric economy is helpful in this examination, particularly his differentiation between commodities (objects developed for exchange value) and singularities (objects valued outside of and above exchange values). In his research about the Nigerian Tiv, he identifies three spheres with a moral hierarchy: at the low end are objects produced for the market, at the midpoint are objects involved in social maneuverings such as prestige objects, and at the high end of the moral hierarchy are objects associated with the rights and obligations of kinship, including people, which he calls the intimate domain (64-91).

By applying this type of multi-centric model to the spheres of the arpilleras, the possible interpretations of why and how the arpilleras affected social justice within and outside Chile come forth. Whereas in Kopytoff's example the objects are the focus of the sphere, in the arpillera model the actor groups become the spheres and their interpretation of the arpilleras as being familiar or distinct within a particular time or phase results in multiple meanings consistent with de Certeau's fluidity of meaning and aligned with the moral hierarchy concept.

David Graeber argues that singularities obtain their distinction and resulting increased moral scale due to the history attached to the object (34). In the case of the arpillera, the history that is infused into the artifact, based on narratives of life stories and social injustice, creates a rich motif and historical significance. 
The actors' interpretation of the arpilleras as familiar or distinct impacts the singularity value of the arpilleras. The moral value or scale (see Fig. 1) varies depending on the time period and actor group but distinctiveness is closely aligned with an increased moral value, in this case ideals of social equity, the right to earn a living, fair treatment, human rights, freedom of speech, and solidarity.

Interestingly, the actor groups' perceptions of the familiarity and distinctiveness vary through time and context. The supporter group, evidenced by their willingness to facilitate workshops, smuggle arpilleras out of Chile, and assist in selling arpilleras worldwide, always acknowledged the distinctiveness of the arpilleras. The creators and oppressors both lacked the insight to distinguish the arpilleras as distinctive in the trauma and survival stages. In the third phase of healing and recovery, the value of the arpilleras rose as support, international media accounts, and military surveillance and appropriation of the arpillera intensified. Once the oppressors/military government felt that the threat of the arpilleras had been neutralized, the arpilleras returned to a more familiar form for the oppressors, but the moral scale remained high for creators and supporters because the arpilleras functioned as circulating memorials. As memorials, the distinctiveness and moral scale increased, consistent with Kopytoff's identification of kinship and Graeber's addition of historical context. In the final stage of continuing circulation, the adoption of the arpilleras as "ambassadors" for the Chilean Bicentennial and international workshops and exhibits again propelled the arpilleras to a distinctive form with high moral value.

\section{CONTRIBUTIONS OF THE ARPILLERAS TO PEACE AND SOCIAL JUSTICE}

The question of how arpilleras positively impacted social justice among the women left behind in their communities, country, and beyond has been explored through the lens of multi-centric actors who appropriate the arpilleras for different uses at different times. Applying the attributes of distinctiveness, familiarity, and moral scale furthers our understanding of why the arpilleras garnered attention and success in communicating human rights violations and promoting solidarity. Several themes related to the contributions to social justice emerged from the five phases of the arpillera life cycle.

First, the arpilleras created a "safe" form of communication to voice what had been silenced during the time of oppression. The arpilleras were a "safe" form of communication when the women were too traumatized to publicly speak about the human rights violations as well as being safe for the women to create when the military viewed them as women's work. And later, when the time of reconciliation 
created a national narrative that excluded details of human abuse, the arpilleras continued to tell the full stories in a non-threatening manner.

Through the process of creating the testimonial textiles, an opportunity emerged for marginalized women to tell their stories and to gain strength in their resolve to survive and to resist the hegemony of the military repression. In this transformation, the women became peaceful yet forceful protestors. The increasing legitimacy and high moral scale of the arpilleras throughout the world also contributed to the arpillerista's increased resolve. In addition, the boldness of the women served to give notice to the military junta that the people would no longer be intimidated by terror tactics.

Documenting human rights atrocities during a time of dictatorship is a tenuous effort. The arpilleras are further distinguished by the fact that they were created as the atrocities were occurring. Often social justice art is created after the fact and carries a reflective gaze. The arpilleras, on the other hand, carry a powerful testimonial gaze that cuts to the essential elements of the abuses.

The arpilleras, made of seemingly useless materials by women who were seemingly inconsequential, serve as an enduring and haunting example of how marginalized people can speak when spirits, lives, and language are silenced.

The continuing circulation of the arpilleras extends the international activist network: ${ }^{13}$ to activities during times of oppression and pre-transitional environments through the organization of supporter groups who make possible the selling and circulating of arpilleras.

The collective processes surrounding arpilleras also set the stage for the time of kairos, as described by Eric Doxtader by facilitating group formation around a common theme that leads to re-gaining individual and collective agency after human rights crises, a necessary pre-cursor to the time when people are ready to come to the table together and seek ways to reconcile.

Positive impacts on social justice goals, shown through the framework of familiar yet distinct and associated moral scales, demonstrate how the familiar aspects of the work made arpilleras "safe" and how the distinct elements successfully pushed the arpillera work into the realm of resistance, subversion, political activism, and international solidarity efforts.

Additionally, the creation of the arpilleras speaks to the need of traumatized people and societies to tell the stories, acknowledge truth, document and preserve history, and to grieve, heal, and move forward. All of these essential components 
have been shown to occur through the creation of arpilleras and illustrate the resilience of oppressed people and the power of the human spirit. 


\section{Appendices}

Fig. 1: Life Cycle of the Arpilleras

\begin{tabular}{|c|c|c|c|c|}
\hline & CREATOR & OPPRESSOR & SUPPORTER & MORAL SCALE \\
\hline TRAUMA & $\begin{array}{l}\text { Familiar form, } \\
\text { therapeutic craft }\end{array}$ & $\begin{array}{l}\text { Familiar, women's } \\
\text { work }\end{array}$ & $\begin{array}{l}\text { Distinct, income } \\
\text { potential }\end{array}$ & Low \\
\hline SURVIVAL & $\begin{array}{l}\text { Familiar, } \\
\text { potential income }\end{array}$ & $\begin{array}{l}\text { Familiar, largely } \\
\text { ignored }\end{array}$ & $\begin{array}{l}\text { Distinct, support } \\
\text { for solidarity }\end{array}$ & Increasing \\
\hline $\begin{array}{l}\text { HEALING \& } \\
\text { RECOVERY }\end{array}$ & $\begin{array}{l}\text { Distinct, } \\
\text { subversive } \\
\text { communication }\end{array}$ & $\begin{array}{l}\text { Distinct, } \\
\text { appropriated for } \\
\text { state messages }\end{array}$ & $\begin{array}{l}\text { Distinct, cloth } \\
\text { documentation } \\
\text { of human rights } \\
\text { abuses }\end{array}$ & High \\
\hline REMEMBERING & $\begin{array}{l}\text { Distinct, } \\
\text { Circulating } \\
\text { Memorials }\end{array}$ & $\begin{array}{l}\text { Familiar, threat } \\
\text { neutralized }\end{array}$ & $\begin{array}{l}\text { Distinct, status } \\
\text { as archives of } \\
\text { period when } \\
\text { spoken and } \\
\text { written language } \\
\text { forbidden }\end{array}$ & High \\
\hline $\begin{array}{l}\text { CONTINUING } \\
\text { CIRUCLATION }\end{array}$ & $\begin{array}{l}\text { Distinct, model } \\
\text { for subversive } \\
\text { communication }\end{array}$ & $\begin{array}{l}\text { Distinct, used } \\
\text { in museums } \\
\text { and public } \\
\text { commemorations }\end{array}$ & $\begin{array}{l}\text { Distinct, status } \\
\text { as worldwide } \\
\text { art form of } \\
\text { resistance }\end{array}$ & High \\
\hline
\end{tabular}




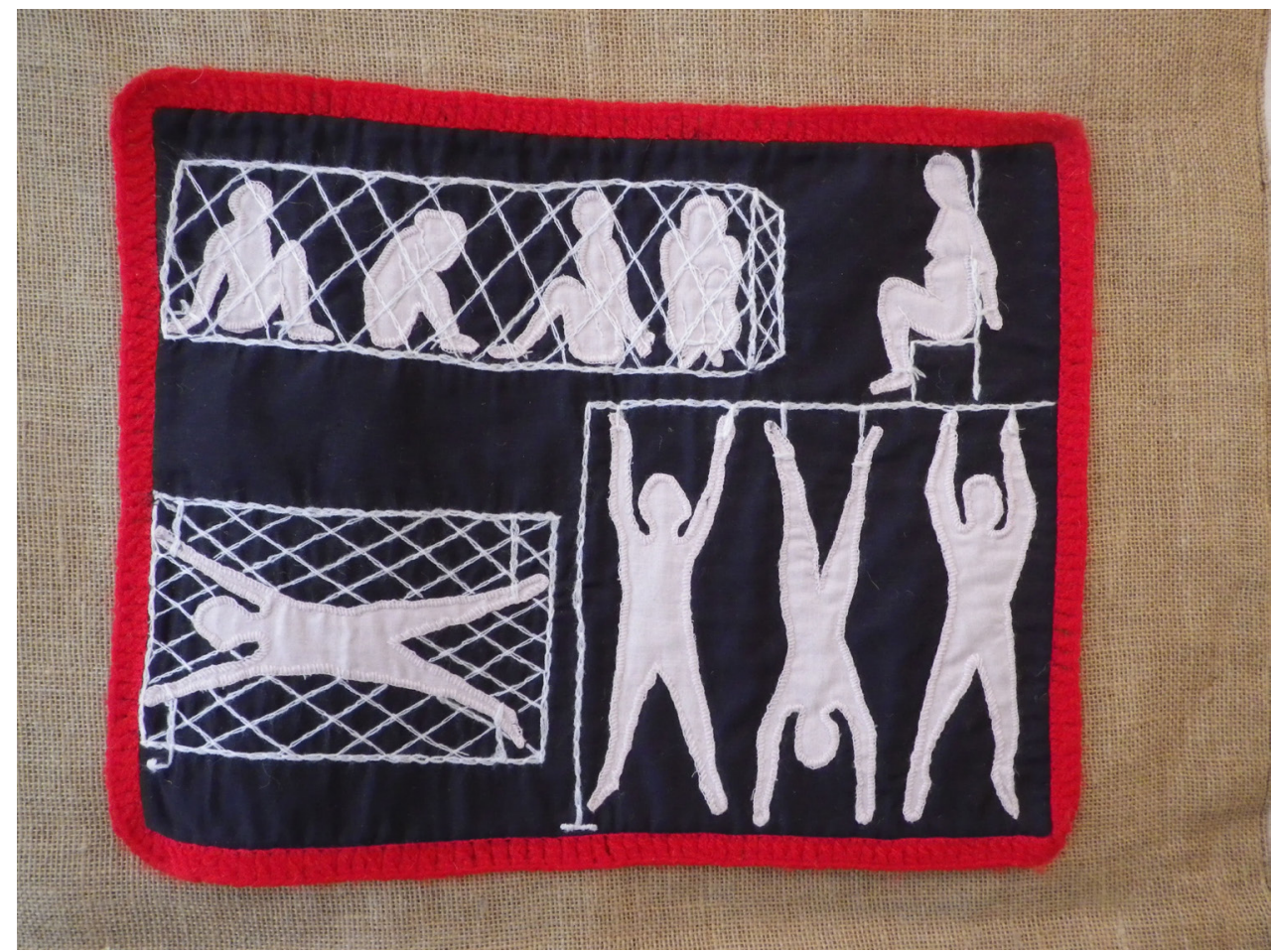

Fig. 2.Phase 1: Trauma-A striking depiction of techniques used to torture women in Chile beginning with the military take-over in 1973 and continuing through the 1980 os.

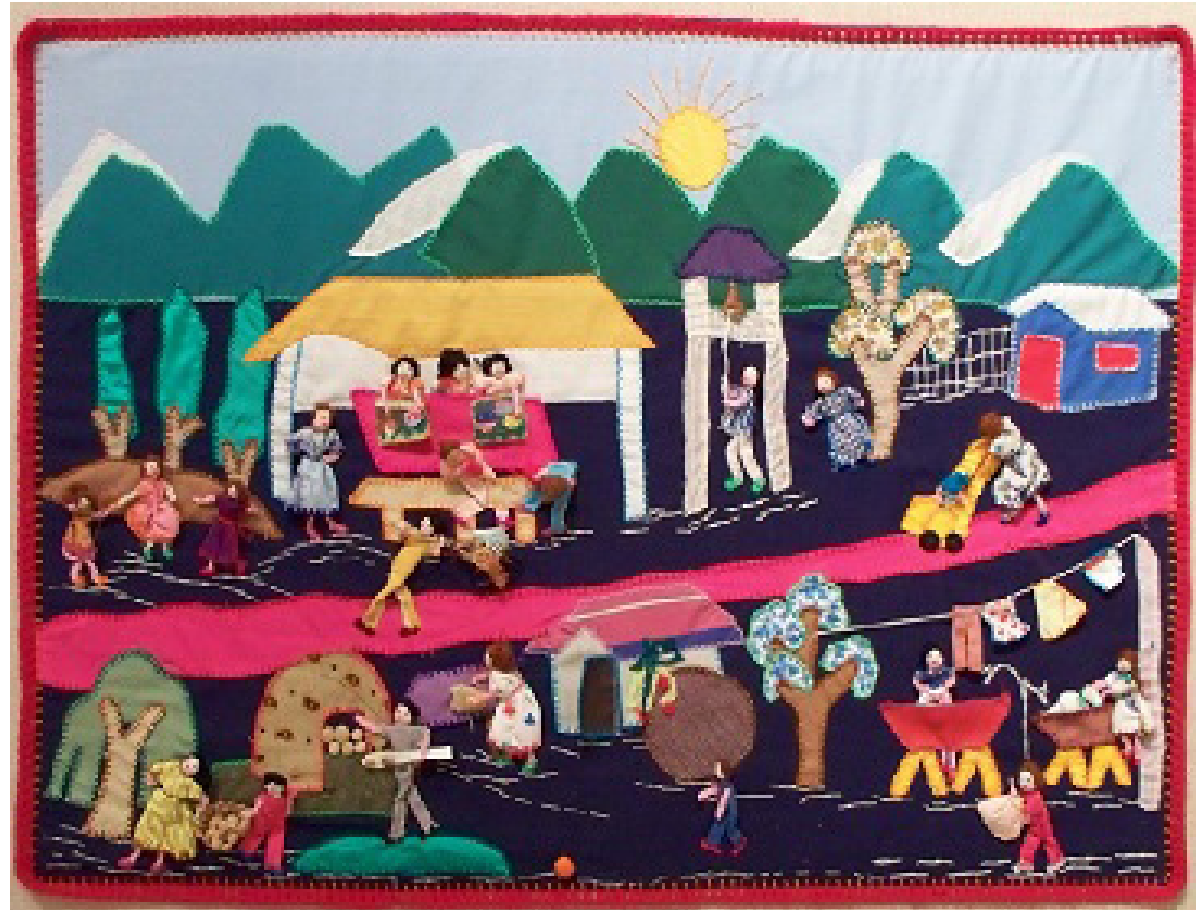

Fig. 3. Phase 2: Survival-During this period the women worked together to provide for their families and create community. 


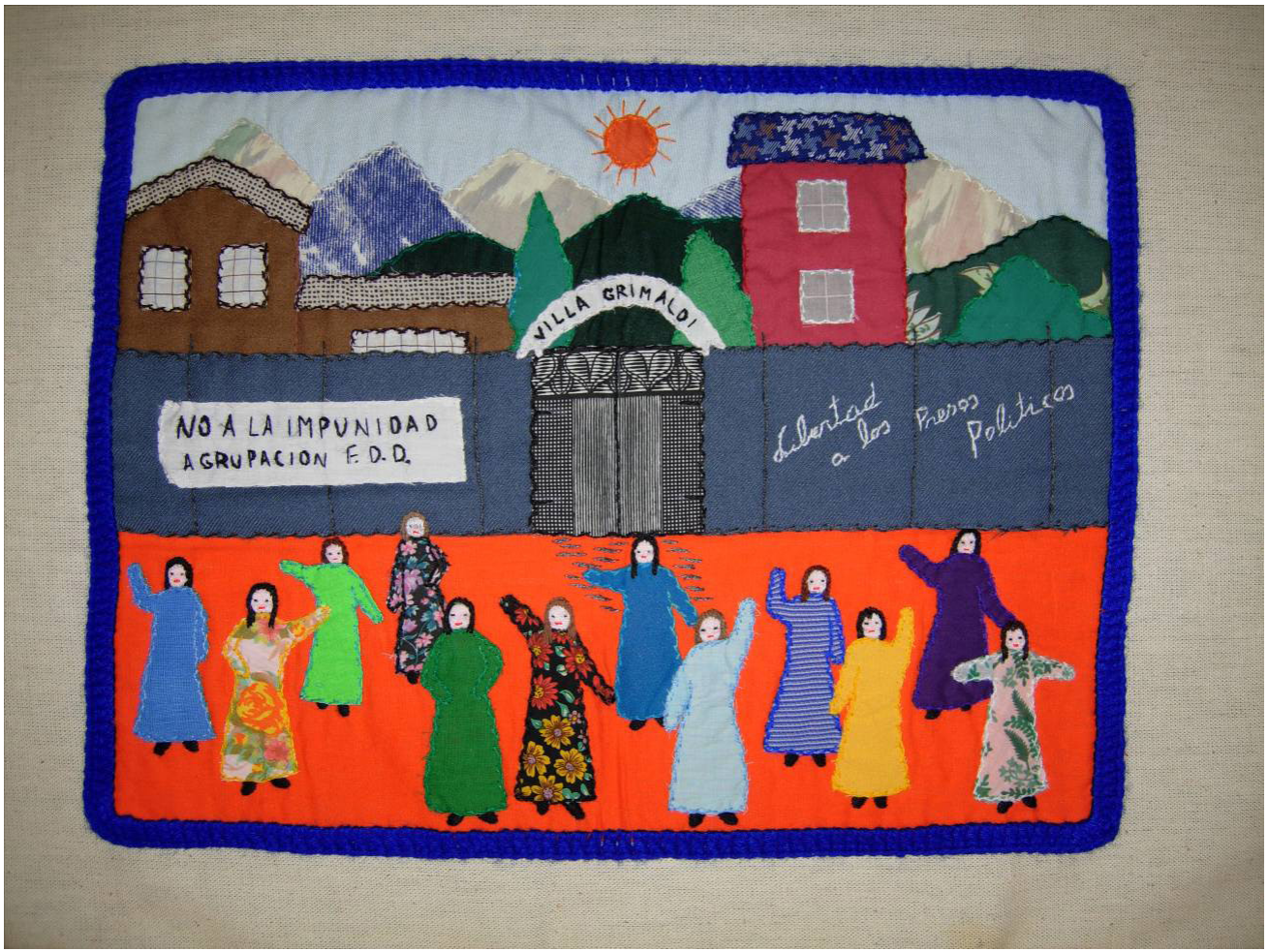

Fig. 4. Phase 3: Healing \& Recovery-Women protesting at Villa Grimaldi, one of the most notorious detention and torture centers in Santiago, Chile. 1989.

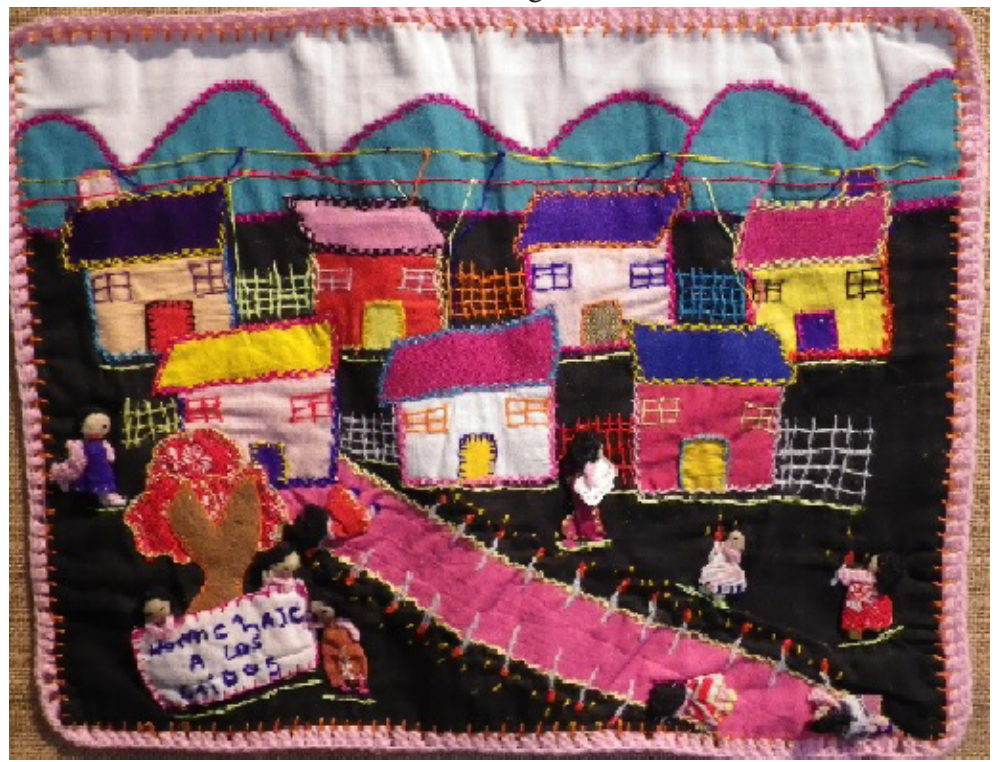

Fig. 5. Phase 4: Remembering-Despite government surveillance, this arpillera shows women openly commemorating the memories of loved ones who remained missing. 


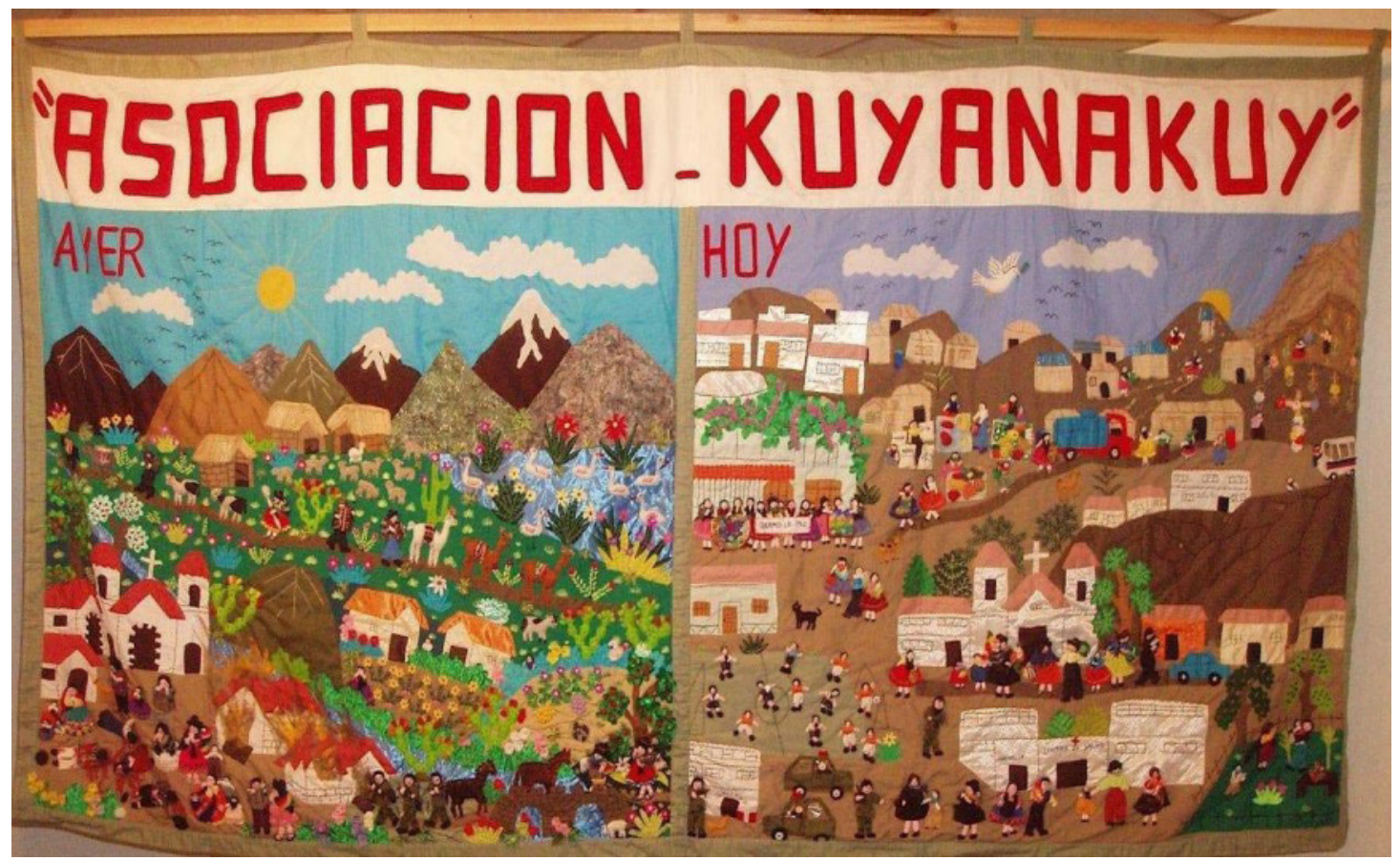

Fig. 6. Phase 5: Continuing Circulation-Peruvian arpillera presented to Truth and Reconciliation Commission in 2002. For more information: see Escola de Cultura de Pau.

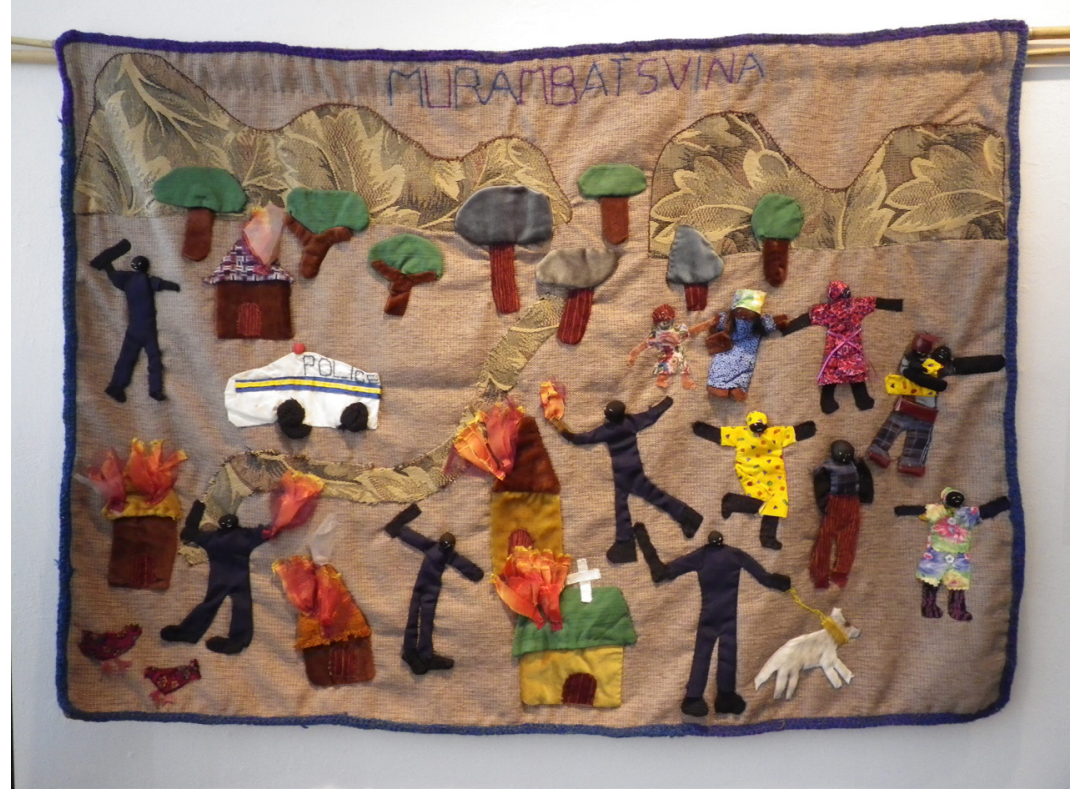

Fig. 7. Phase 5: Continuing Circulation-This arpillera depicts the destruction by the Zimbabwe government of Killarney in May 2005 in which an estimated 500,000 people were displaced within a month. 


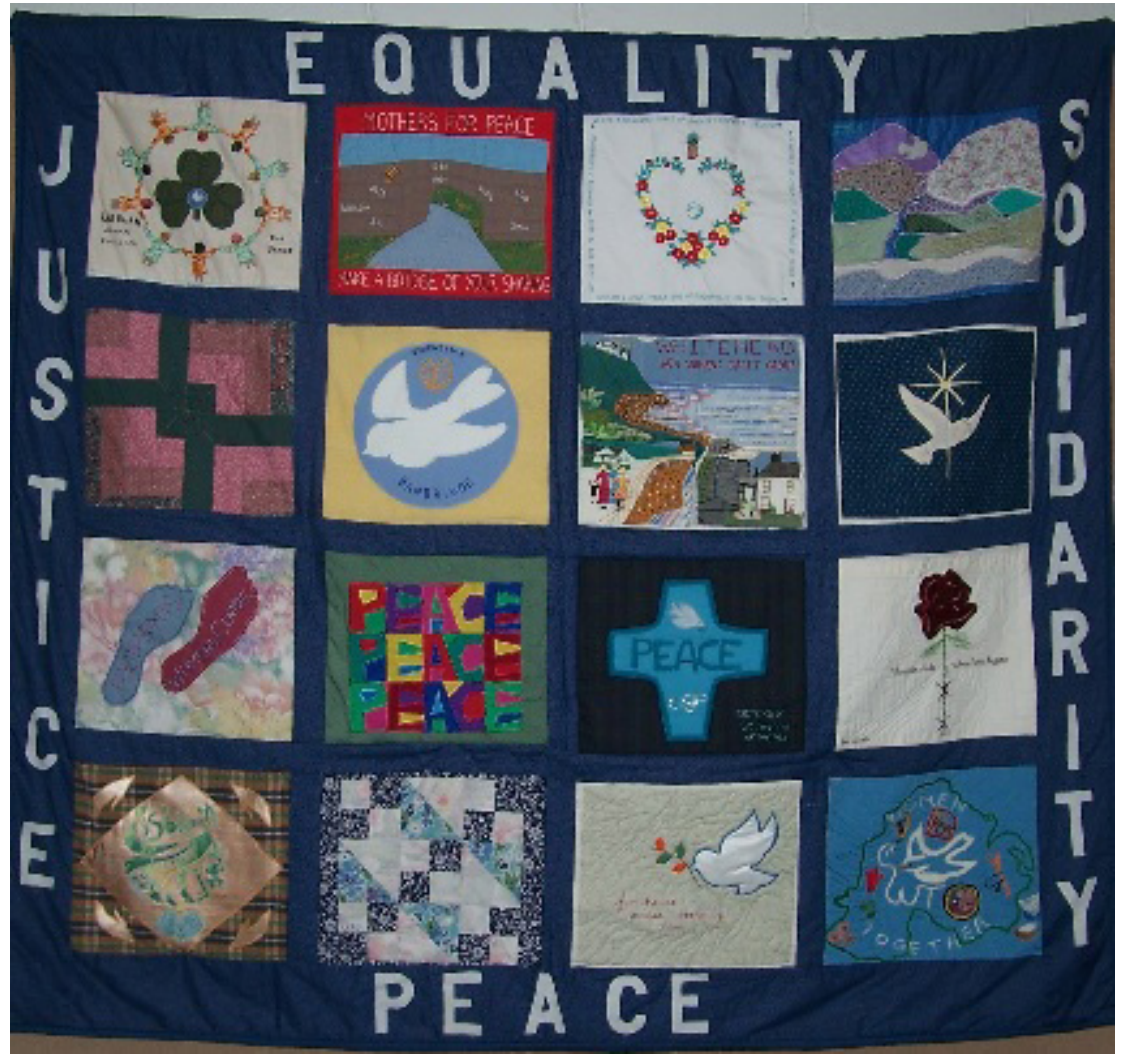

Fig. 8. Phase 5: Continuing Circulation-One of several community arpilleras created to honor the memory of lives lost during The Troubles and to commemorate the 1oth anniversary of the Good Friday Agreement in Northern Ireland (2008). 


\section{Notes}

1. In an effort to counter the impact of the arpilleras and create narratives about a content civil society, the dictatorship enlisted supporters to create pro-government arpilleras. Sharon Taylor made several trips to Chile during this time and was taken to the state-run workshops that were set up to sell "official" arpilleras to tourists.

2. Nearly $95 \%$ of the victims were male and $60 \%$ were aged 30 or younger (Morris 210).

3. The word arpilleras refers to the sack cloth material that comes from agricultural products and was used, as a found object, as the backing for the small (approximately 16 x 20") cloth documents.

4. As noted in the second edition of Tapestries of Hope, Threads of lLove, The Arpillera Movement in Chile by Marjorie Agosin.

5. The question raised is whether the new government should have pushed the military to provide information for the truth-finding effort in the face of continued military threats. Ensalaco notes that transitional governments are full of risk and asks if sacrificing justice is prudent in these cases (236).

6. A presidential commission, in contrast to a parliamentary commission, gave Aylwin more flexibility regarding how the commission was run, the outcome, the form of the report, and oversight (Ensalaco).

7. During the investigation process, former president and now armed forces General Augusto Pinochet, in an effort to intimidate the commission, put the military on nationwide alert. "Pinochet's stunt was meant to convey the simple but ominous message that the possibility of military intervention was now part of operational doctrine" (Ensalaco 203).

8. The Valech Report was released in 2004 and specifically focused on victims of torture whereas the Rettig Report addressed people who had been disappeared. Bacic and Stanley, in their summary article on the Valech Commission, note that there were 1,132 detention centers across Chile that were used as torture centers. Beginning with the coup and continuing until 1990 when Aylwin became president, torture was institutionalized and "preceded most of the executions and 'disappearances' of victims" (1). Proven cases of detention numbered 33,221 but the authors note that many people still did not trust the government and refused to come forward to provide testimony.

9. Quoted from a personal interview with Roberta Bacic.

10. In the mid-1980s the government reaction to the arpilleras was covered internationally. See, for example, the New York Times coverage in 1984: "Chilean Arpillerista's Fight Back."

11. For background on Peru and Northern Ireland see Bacic and Sanfeliu.

12. Roberta Bacic, an international human rights advocate, has spearheaded many of these efforts. 
13. Lutz and Sikkink identify global activist groups as the "justice cascade," international activists who work in tandem to bear pressure upon governments to eliminate human rights abuses (6-7). 


\section{Works Cited}

Agosin, Marjorie. Tapestries of Hope, Threads of Love. The Arpillera Movement in Chile. Lanham: Rowman \& Littlefield, 2008. Print.

--. Scraps of Life, Chilean Arpilleras. Trenton: Red Sea, 1987. Print.

Aguilar, Mario. "The Mesa de Dialogo and the Fate of the Disappeared in Chile 1999-20oo: National Forgiveness Without Political Truth?" Reconciliation, Nations and Churches in Latin America. Ed. I. Maclean. Burlington: Ashgate, 2006. 41-55. Print.

Appadurai, Arjun. Modernity at Large. Minneapolis: U of Minnesota P, 1996. Print.

Bacic, Roberta. "Dealing with the Past: Chile Human Rights and Human Wrongs." Race \& Class: A Journal for Black and Third World Liberation 44.1 (2002):17-31. Print.

--. "A Brief Testimony about the Chilean Churches' Commitment to Human Rights During Pinochet's Dictatorship." Committee for Conflict Transformation and Support Review 21. 2003. Print.

--. Personal Interview. Guest Curator, International and Chilean Arpilleras Exhibit, Derry, Northern Ireland and Investigator, Chilean National Corporation of Reparation and Reconciliation, 1993-1996, March-April 2008.

Bacic, Roberta and Alba Sanfeliu. A Conversation about Arpilleras and Quilts as Artistic and Emotional Self. Eds. T. Randahl Morris and Mitzi Bales. Escola de Cultura de Pau, Universat Autonoma de Barcelona, Spain. 2008. Web. 2015.

Bacic, Roberta and Elizabeth Stanley. Dealing with Torture in Chile. Achievements and Shortcomings of the Valech Report. Beitrage, 2005. 1-10. Print.

Baldez, Lisa. Why Women Protest: Women's. Movements in Chile. Cambridge: Cambridge UP, 2002. Print.

Chilean Arpilleras. www.facinghistory.org. n.d. Web. 12 Feb. 2010.

"Chilean Arpillerista's Fight Back." imagingenocide.wordpress.com. 2 May 2013. Web. 2015.

Chilean National Commission for Truth and Reconciliation. "Report of the Chilean National Commission on Truth and Reconciliation (Rettig Report)." United States Institute of Peace Truth Commission Digital Collection, 1991. n.d Web. 12 Jan. 2008.

Cooper, Marc. Pinochet and Me. New York: Verso, 2001. Print.

Doxtader, Erik. With Faith in the Works of Words. The Beginnings of Reconciliation in South Africa, 1985-1995. Michigan: Michigan State UP, 2009. Print.

Ensalaco, Mark. Chile Under Pinochet. Recovering the Truth. Philadelphia: U of Pennsylvania P, 200o. Print.

Franco, Jean. "Gender, Death and Resistance: Facing the Ethical Vacuum." Critical Passions, Selected Essays. Durham: Duke UP, 1999. 18-38. Print.

Graeber, David. Toward an Anthropological Theory of Value. New York: Palgrave, 2001. Print.

Jenkins, Henry. Textual Poachers. New York: Routledge, 1992. Print.

Kopytoff, Igor. "The Cultural Biography of Things: Commoditization as Process." The Social Life of Things: Commodities in Cultural Perspective. Ed. Arjun Appadurai. Cambridge: Cambridge UP, 1986. 64-91. Print. 
Kornbluh, Peter. "Introduction." Tapestries of Hope, Threads of Love. The Arpillera Movement in Chile, $2^{\text {nd }}$ ed. Marjorie Agosin. Lanham: Rowman \& Littlefield, 2008. 1-12. Print.

Lerche, Charles. "Truth Commissions and National Reconciliation: Some Reflections on Theory and Practice." Peace and Conflict Studies 7.1 (2000): 1-20. Print.

Lutz, Ellen and Katheryn Sikkink. "The Justice Cascade: The Evolution and Impact of Foreign Human Rights Trials in Latin America." Chicago Journal of International Law 2.1 (2001): 1-33. Print.

Maclean, Iain. Reconciliation, Nations and Churches in Latin America. Vermont: Ashgate, 2006. Print.

Roht-Arriaza, Naomi. The Pinochet Effect. Transnational Justice in the Age of Human Rights. Philadelphia: U of Pennsylvania P, 2005. Print.

Stitching Truth. www.facinghistory.org. 2010. Web. 1 Dec. 2009.

Taylor-Tidwell, Sharon Ann. "Visual Narrative in Chilean Arpilleras: Testimonios Graficos." PhD diss., U of Michigan, 1993. Print. 